\title{
HETEROGENE OUDERENZORG IN SCANDINAVIË
}

De Nederlandse verzorgingsstaat verandert en om de transitie van verzorgingsstaat naar participatiesamenleving in goede banen te leiden wordt naar het buitenland gekeken. Het Scandinavische model heeft een voorbeeldfunctie, maar studenten van Professionshøjskolen Metropol (Kopenhagen) zijn duidelijk. Het Scandinavische model is niet compleet en nooit compleet uitgevoerd.

Wetenschappelijke onderzoeken en beleidsdocumenten uit Scandinavische landen bevestigen wat de studenten als probleem benoemen tijdens een door Saxion verzorgd gastcollege in Kopenhagen. Er is discriminatie en racisme. Nieuwkomers worden uitgesloten. Mantelzorgers hebben last van overbelasting, spanning tussen arbeid en zorgtaken en beperkte tijd voor persoonlijke ontwikkeling. Het Scandinavische verzorgingsstaatmodel (Nordic Model) blijkt niet langer houdbaar. Zweden, Noorwegen, Denemarken en Finland verlaten daarom het universalisme (een allesomvattend stelsel van sociale zekerheid voor iedere inwoner) en introduceren particularisme (marktwerking). Dat moet oplossingen bieden voor knelpunten in onder meer de ouderenzorg. Marktwerking blijkt echter te leiden tot een toename van overheidsregels, terwijl de kwaliteit van de zorg afneemt. (Meagher \& Szebehely, 2013).

\section{BEDREIGINGEN}

Vooralsnog bevinden de Noord-Europese landen zich in een luxepositie, waardoor zij het zich kunnen veroorloven om mensen te onderhouden als zij niet werken. Het wordt echter steeds lastiger uitkeringsgerechtigden te bereiken, terwijl actieve burgers nu zo hard nodig zijn om de verzorgingsstaat te kunnen blijven betalen (Kuiper, Van de Velde, Van Zuydam, 2012). 'Met de hervormingen die de Scandinavische landen in de jaren negentig doorvoeren lijkt het Scandinavische model gered, waarbij een grotere invloed van de civil society een rol speelde, maar vijf jaar geleden ontstond opnieuw een discussie over de houdbaarheid ervan' (Kuiper, Van de Velde, Van Zuydam, 2012). De Noord-Europese raad (waarin Zweden, Noorwegen, Denemarken en Finland zijn vertegenwoordigd) constateert dat het Nordic Model drie bedreigingen kent: mondialisering, ideologie en marginalisering en uitsluiting. Mondialisering leidt ertoe dat in een hoog tempo steeds meer hoger opgeleiden uit lagelonenlanden op de arbeidsmarkt verschijnen. Zij kunnen concurreren met de dure kenniswerkers in de Scandinavische landen. Ideologische veranderingen leiden tot andere opvattingen over de gewenste rol van de overheid. Na decennia waarin de verzorgingsstaat zonder veel discussie steeds verder uitgebouwd kon worden, besloten Scandinavische regeringen in de jaren '90 
marktwerking te introduceren, in de hoop dat dat de dienstverlening efficiënter zou maken. Korten op overheidsdiensten leidt echter direct en zichtbaar tot in- en uitsluiting. De rijken kunnen een private gezondheidszorgverzekering afsluiten, armen staan met lege handen.

\section{OUDERENZORG}

Als gevolg van bedreigingen, veranderende politieke opvattingen, de snelle toename van het aantal ouderen (verwachtingen van voor 2020 zijn al bereikt) en om de dienstverlening aan het toenemend aantal ouderen te kunnen garanderen kiezen Denemarken, Finland, Noorwegen en Zweden voor een breuk met het verleden. Het historisch gegroeide systeem van kwalitatief goede en door de overheid gefinancierde zorg aan ouderen wordt ingeruild voor New Public Management (NPM - marktwerking in overheidstaken, waarin efficiëntie en effectiviteit centraal staan). Lokale overheden en marktpartijen gaan samenwerken (Meagher \& Szebehely, 2013). In dat systeem worden ten eerste winstgevende arrangementen geïntroduceerd naast non-profit arrangementen. Ten tweede worden overheidstaken in handen gegeven van marktpartijen. Ten derde krijgen ouderen meer keuzemogelijkheden door een toenemend aantal aanbieders van zorg waarmee lokale overheden contracten hebben afgesloten. Ten vierde worden belastingmaatregelen genomen die het voor ouderen met een bovenmodaal inkomen aantrekkelijk maken om zorg uit de markt af te nemen. De kosten voor thuiszorg zijn in Zweden fiscaal aftrekbaar voor ouderen of (als die betalen) voor hun kinderen. In Finland en Zweden krijgen aanvragers van thuiszorg vouchers, waarmee ze zelf een keuze kunnen maken uit het lokale zorgaanbod. Deze worden uit belastingopbrengsten bekostigd, maar gebruikers betalen wel een inkomensafhankelijke eigen bijdrage. Voor hogere inkomens is het echter in veel gevallen aantrekkelijker om de zorg uit eigen zak te betalen. Dat is door het fiscale voordeel vaak niet of nauwelijks duurder dan de voucherregeling en bovendien heeft iemand die zelf zijn zorg betaalt geen indicatiestelling nodig. Daarnaast kunnen aanvullende diensten worden ingekocht, die private partijen wel en publieke zorginstellingen niet mogen aanbieden. Werd de ouderenzorg gekenmerkt door een gelijke mate van toegankelijkheid voor iedereen, zonder belemmeringen op grond van inkomen of bezit, nu lijkt marktwerking hier een einde te maken. Die ongelijkheid wordt versterkt door verschillen tussen gemeenten en landen (Meagher \& Szebehely, 2013).

\section{HETEROGENITEIT}

In Noorwegen en Denemarken beperkt marktwerking zich vooralsnog tot zorg aan huis (vergelijkbaar met Nederlandse thuiszorg). In Finland en Zweden gaat het al verder zoals 
blijkt uit het Finse Loppukiri, een woongemeenschap voor bewoners van middelbare leeftijd (48+) en ouder die aandeelhouder zijn en op basis van het aantal aandelen in het project besluiten mogen nemen over bedrijfsvoering en toekomst van het project. Het aantal Zweedse gemeenten dat de zorg uitbesteedt was in 1993 nog slechts 10\%, maar in 2003 al 82\%. In 2010 werd 19\% van de thuiszorg in Zweden door private ondernemingen (al dan niet met winstoogmerk) geleverd. Er zijn echter grote verschillen tussen gemeenten. Zo wordt in Stockholm 60\% van de thuiszorg door private ondernemingen geleverd en in Gotenburg helemaal niets (Meagher \& Szebehely, 2010). Daarnaast is in alle landen een ontwikkeling zichtbaar die inzet op ouderenzorg in de breedste zin van het woord. Ouderenzorg gaat niet slechts over het aanbieden van zorg. Het gaat om het kweken van ondernemerschap in alle bevolkingsgroepen, waardoor afhankelijkheid van de overheid minder wordt (Meagher \& Szebehely, 2013). Het gaat over anders inrichten van de economie en de infrastructuur. Zo kunnen ouderen langer werken en reizen, maar familie en buren ook sneller en flexibeler ondersteuning bieden. Dit moet uiteindelijk leiden tot diverse vormen van informele zorg (vergelijkbaar met de mantelzorg en georganiseerde vrijwillige zorg in Nederland waar gemiddeld, mantelzorg en vrijwilligerswerk met zorgtaken in georganiseerd verband, 24 uur informele zorg per persoon per maand wordt geleverd). Dat hiervoor nog stappen gezet moeten worden blijkt uit statistieken over Zweden waar nu nog veel minder mantelzorgers zijn dan in Denemarken en Noorwegen, hoewel zij per persoon wel meer zorg leveren (respectievelijk 16 uur, 12 uur en 14 uur per persoon per maand). De kenmerken van de zorgverleners en zorgontvangers is verspreid over de landen heel divers. In Denemarken zijn het vooral hoger opgeleiden en burgers met een laag inkomen die informele zorg verlenen. In Noorwegen en Zweden leveren mannen minder informele zorg dan vrouwen en burgers in Oslo en Stockholm leveren meer informele zorg dan burgers in Kopenhagen. Finland heeft in het geheel een aparte status. Twintig jaar geleden is daar al radicaal gebroken met het centraal aansturen en financieren van ouderenzorg. Lokale overheden zijn verantwoordelijk, maar hebben slechts een beperkt budget. Dit lijkt overigens in het landelijke en uitgestrekte Finland de beste oplossing voor het ontstaan van informele zorg. Hoe kleiner het aanbod van formele zorg, hoe groter het aanbod van informele zorg (Jakobsson, Kotsadam, Szebehely, 2013).

\section{TOEKOMST}

Het geroemde en gerespecteerde Scandinavische verzorgingsstaatmodel, dat gelijkheid (universalisme) en bescherming van burgers voorop stelt blijkt onhoudbaar. Met marktwerking (particularisme) en heterogeniteit moet in de toekomst bescherming van 
kwetsbare burgers gegarandeerd worden. Hoewel er nog weinig onderzoek is gedaan, blijkt dat particuliere zorgaanbieders economische kansen zien in het heterogene model, omdat de overheid weinig belemmeringen oplegt (Meagher \& Szebehely, 2013). Overheden, ondernemers en burgers die samen een heterogeen verzorgingsstaatmodel bouwen kunnen inspirerend zijn voor de Nederlandse situatie. Er worden immers maatschappelijke taken en verantwoordelijkheden gedecentraliseerd. Lokale overheden (waaronder gemeenten) krijgen meer verantwoordelijkheid voor uitvoering en financiering van beleid, maar er wordt tegelijkertijd bezuinigd op het budget. Er ontstaat ook in Nederland behoefte aan meer particuliere inzet (burgers en ondernemingen) in het publieke domein. Uit onderzoek in zowel de Verenigde Staten als in Groot Brittannië en Australië blijkt echter dat met de groei van marktwerking in de ouderenzorg het aantal regels evenredig meegroeit, maar de kwaliteit evenredig afneemt (Meagher \& Szebehely, 2013). Dat dit wordt geconstateerd in Scandinavisch onderzoek is veelzeggend.

\section{OVER DE AUTEURS}

Jillis Kors is docent \& onderzoeker (Saxion). Ben Boksebeld is docent (Saxion) en promovendus (Universiteit Twente). Met dank aan Minna Zechner (Seinäjoki UAS).

\section{LITERATUUR}

Jakobsson, N., Kotsadam, A., Szebehely, M. (2013). Informal eldercare and care for disabled children in the Nordic countries: prevalence and relation to employment. In: NJSR - Nordic Journal of Social Research (4), 1-30.

Kuiper, M., Velde, B. van de, Zuydam, S. (2012). Leren van vermaatschappelijking in het Verenigd Koninkrijk, Australië en Scandinavië. Utrecht: Universiteit Utrecht.

Meagher, G. \& Szebehely, M. (2013). Marketisation in Nordic eldercare. A research report on legislation, oversight, extent and consequences. Stockholm: Stockholm University.

Meagher, G. \& Szebehely, M. (2010). Private Financing of Elder Care in Sweden. Arguments for and Against. Stockholm: Institute for Future Studies. 